\title{
Corporate spinoffs and executive compensation
}

\author{
Justin Law ${ }^{1 *}$ and Wayne $\mathrm{Yu}^{2}$
}

\author{
* Correspondence: afjustin@polyu. \\ edu.hk \\ ${ }^{1}$ School of Accounting and Finance, \\ The Hong Kong Polytechnic \\ University, Hung Hom, Hong Kong, \\ China \\ Full list of author information is \\ available at the end of the article
}

\begin{abstract}
This paper investigates the impact of corporate spinoffs on executive compensation. We find no significant association between executive compensation and stock returns prior to spinoffs, but a significant positive association between the two afterwards. We also find evidence that corporate governance generally improves after the spinoff. In addition, the positive association between executive compensation and stock returns is more pronounced for firms with greater improvements in their corporate governance. Overall, our findings support the notion that spinoffs create value by reducing agency costs.

Keywords: Spinoffs, Corporate governance, CEO compensation

JEL classification: G32, G34, J33
\end{abstract}

\section{Introduction}

Spinoff is a unique form of corporate re-organization in that it creates value (Hite and Owers 1983; Miles and Rosenfeld 1983; Schipper and Smith 1983; Cusatis et al. 1993) without any cash being involved in the process. One explanation advanced in the spinoff value-creation argument is the reduction of agency costs arising from prior corporate diversifications. Specifically, spinoffs reduce agency costs by dismantling internal capital market inefficiencies, improving governance structures, and enhancing contracting efficiency.

In this study, we analyse how spinoff improves contracting efficiency by examining CEO compensation contracts. Specifically, we examine the impact of spinoff on pay-performance sensitivity of CEO compensation for spinoff parent firms. If spinoff improves contracting efficiency, it will promote interest alignment between CEOs and shareholders. Consequently, the CEO pay-performance sensitivity will be improved after spinoff (the interest alignment hypothesis). Alternatively, the CEO may also to use spinoff as an opportunity to re-negotiate his/her compensation contract to hedge against additional business risk as the firm is becoming less diversified. As a result, the CEO pay-performance sensitivity may be impaired after spinoff (the risk aversion hypothesis).

Next, we extend the study to examine the role of corporate governance present in spinoff firms on CEO compensation. We use four components of corporate governance mechanisms: board structure, committee independence, board and committee

(C) The Author(s). 2018 Open Access This article is distributed under the terms of the Creative Commons Attribution 4.0 International License (http://creativecommons.org/licenses/by/4.0/), which permits unrestricted use, distribution, and reproduction in any medium, provided you give appropriate credit to the original author(s) and the source, provide a link to the Creative Commons license, and indicate if changes were made. 
activities, and institutional ownership. We then combine the scores of the four individual governance mechanisms to investigate the impact of overall governance on CEO pay.

We briefly summarize our findings as follows. Based on a sample of 75 firms spanning the period from 1990 to 1997, CEOs received more stock options after spinoff. This observation is consistent with Seward and Walsh (1996), as well as Jensen et al. (2004), who document a substantial rise in the use of stock options from 1992 to 2000. More importantly, we find that pay-performance sensitivity improves significantly for the parent firm after a spinoff using stock return as a measure for corporate performance. This finding lends support to the interest alignment hypothesis, which complements the extant literature on the agency cost reduction explanation of spinoff value creation (e.g. Gertner et al. 2002; Burch and Nanda 2003; Ahn and Walker 2007). Third, corporate governance generally improves after spinoff, and the improvement in the CEO pay-performance sensitivity after spinoff is more pronounced for firms with greater corporate governance improvement.

Our study contributes to the literature by extending the contracting efficiency proposition to empirically examine CEO compensation contracts in spinoff firms. The consideration of compensation contracts using a long-window event study enables us to test both the interest alignment and risk aversion hypotheses stemming from the executive compensation literature. To the best of our knowledge, this is the first long-window event study to examine the impact of CEO compensation contracts on spinoff firms. ${ }^{1}$ In addition, the use of pay-performance sensitivity methodology directly captures the extent of interest alignment improvement from the spinoff transaction. Finally, this study analyses the role of four aspects of corporate governance in improving interest re-alignment for spinoff firms. Notwithstanding the extensive literature on corporate governance, the literature examining the role of board committees, and board and committee activities, is sparse. Our findings on this aspect of governance will contribute to this small yet growing body of governance literature.

The remainder of this paper is organized as follows. Section 2 describes the related literature and the hypotheses tested in this study. Section 3 discusses the data employed in this study. Section 4 presents our key results on the improvement of interest alignment. Section 5 further examines the relation between corporate governance and interest alignment improvement. Section 6 discusses the additional analysis, and Section 7 concludes the paper.

\section{Related literature}

A number of prior studies suggest that spinoff is beneficial to firms as it offers an opportunity to mitigate agency problems. Specifically, a strand of spinoff literature suggests that spinoff mitigates agency problems by dismantling inefficient internal capital markets arising from rent seeking and bargaining activities among divisional managers (Shin and Stulz 1998; Scharfstein 1998; Rajan et al. 2000; Scharfstein and Stein 2000). Consequently, a firm's investment efficiency improves after spinoff. Gertner et al, (2002) document that post-spinoff firms appear to show a stronger positive association with the average industry Tobin's $Q$ and average industry investment as compared to pre-spinoff firms. Similarly, Ahn and Denis (2004) find that post-spinoff firms invest significantly more in high-Q segments. Moreover, spinoffs reduce the investment diversity present in multi-divisional firms, leading to aggregate value gains for the post-spinoff parent and the spun-off entity (Burch and Nanda 2003). 
A related set of findings from spinoff literature claims that spinoff firms reduce agency cost by improving governance. Chemmanur and Yan (2004) argue that spinoffs improve efficiency through managerial discipline. As spinoff firms are more likely to be acquired by rivals, managers are presumably motivated to work harder and therefore bring efficiency improvement. Evidence from a more recent study by Chemmanur et al. (2014) suggests that spinoff improves total factor productivity of firms, starting from the first year and continuing for five years after spinoff. The productivity gain arises from decreases in employment, total salary and material costs. Since the improved productivity of spinoff firms stems from an increase in efficiency rather than an increase in output, and because the productivity increases arise primarily within parent firms after spinoff, the authors argue that the evidence supports the view that spinoffs discipline managers for subsequent performance improvement.

Some studies also suggest that spinoffs are associated with good governance structures. Seward and Walsh (1996) suggest that most of the board members of spun-off firms are outside directors. Ahn and Walker (2007) state that firms with better governance tend to spin off and that the effective governance structure in spinoff firms results in a higher market-to-book valuation after spinoff. Patro (2008) documents that block ownership for spun-off firms increases after spinoff, and that such increase is positively associated with subsequent performance and survival. Chemmanur et al. (2010) find that firms protected by having more antitakeover provisions (ATP) before spinoff are associated with higher announcement returns and enjoy greater post-spinoff operating performance improvements. Additionally, firms which reduce the number of ATP after spinoff are associated with more pronounced operating improvements. Evidence from Feng et al. (2015) indicates that CEOs of firms with stronger equity incentives are more likely to engage in spinoffs, while spinoff firms with weaker CEO equity incentives before the transaction are associated with stronger board independence and a higher percentage of institutional investors.

Another series of studies examines the impact of spinoff on contracting efficiency. Hite and Owers (1983) suggest improvement in contracting efficiency as a potential explanation for the positive abnormal returns associated with spinoff announcements. Similarly, Schipper and Smith (1983) explain that the value created in spinoff stems from the elimination of diseconomies of decision management and diseconomies of decision control. ${ }^{2}$ Aron (1991) provides a theoretical model to demonstrate that spinoff facilitates writing and enforcing performance-based contracts. Seward and Walsh (1996) empirically show that spinoff enables firms to implement more efficient control systems by using a correlation matrix on data related to the spun-off units. However, as these studies do not offer direct evidence regarding CEO compensation, we extend the contracting efficiency perspective by examining the effect of spinoffs on CEO compensation contracts.

Holmstrom (1979) argues that setting an optimal compensation contract can mitigate moral hazard problems. The extant compensation literature also suggests that shareholders' and managers' interests can be aligned by giving the CEO sufficient incentives. This is particularly true where $\mathrm{CEO}$ remuneration is closely tied to firm performance. However, writing an optimal CEO compensation contract is costly in multi-divisional firms because the operating complexities between divisions hinder market monitoring (Aron 1991). Spinoffs remove these contracting costs by separating the multi-divisional firm into two or more entities. Consequently, the post-spinoff parent firms will have 
greater incentive to write stronger performance-based CEO compensation contracts, promoting closer alignment between the interests of the CEO and shareholders. We refer to this as the "interest alignment hypothesis".

In contrast, spinoff effectively increases the CEO's exposure to firm-specific or idiosyncratic risk as the multi-divisional firm becomes less diversified after a spinoff. Thus, the CEO may also consider taking advantage of the spinoff transaction as an opportunity to hedge against the increased risk exposure by re-negotiating his/her compensation contract. From this perspective, the post-spinoff compensation contract will impair the interest alignment of the CEO and the shareholders. We refer this as the "risk aversion hypothesis".

The pay-performance sensitivity measure introduced by Jensen and Murphy (1990) offers a direct approach to examine whether spinoffs can improve contracting efficiency regarding CEO compensation contracts. In essence, this measure captures the extent of interest alignment between the CEO and the shareholders. There is ample empirical evidence that CEO pay is positively tied to firm performance (Hall and Liebman 1998; Murphy 1999; Conyon and Murphy 2000; Lilienfeld-Toal and Ruenzi 2014). Such evidence indicates that the compensation contract promotes a closer interest alignment between the CEO and shareholders. However, some studies report an inverse relationship between pay-performance sensitivity and a firm's risk level, supporting the risk aversion hypothesis (Aggarwal and Samwick 1999; Jin 2002; Garvey and Milbourn 2003; Cao and Wang 2013 etc). ${ }^{3}$

Hence, if a firm takes the opportunity to improve contracting efficiency by restructuring the CEO compensation contract, one would expect the pay-performance sensitivity of the parent firm to experience a positive and significant improvement after spinoff, supporting the interest alignment hypothesis. Alternatively, if the CEO regards the spinoff as an opportunity to negotiate a compensation contract that better hedges against potential risk exposure, we would expect to observe a negative and significant change in pay-performance sensitivity after spinoff, supporting the risk aversion hypothesis.

In this study, we maintain that spinoff offers an opportunity for firms to improve contracting efficiency. This is because spinoff separates the multi-divisional firm into two (or more) entities, making it easier and more effective for the market to monitor the performance of the post-spinoff parent firm. In addition, CEO performance is less susceptible to uncontrollable factors found in pre-spinoff multi-divisional organizations. Accordingly, firms will have greater incentives to design CEO compensation contracts with a stronger performance-based component as writing and enforcing such contracts becomes less costly. Consequently, the interest alignment for the CEO and shareholders would improve after spinoff (i.e., the interest alignment hypothesis). Putting this into the context of pay-performance sensitivity, the following is our hypothesis stated in an alternate form:

\section{H1: CEO pay-performance sensitivity improves after spinoff (interest alignment hypothesis).}

We next examine the effect of corporate governance on CEO pay-performance sensitivity. The extant literature on agency theory and corporate governance suggests that a firm's internal control systems play a vital role in improving such interest alignment (Jensen and Meckling 1976; Fama and Jensen 1983; Jensen 1993). Because firms with stronger governance are more likely to minimize agency costs, we test the following hypothesis as stated in an alternate form: 
H2: CEO pay-performance sensitivity improvement is expected to be more pronounced for spinoff firms with stronger governance.

Finally, the enhancement of CEO pay-performance sensitivity is likely to be more significant for firms with greater improvement in corporate governance after the spinoff transaction. This leads us to hypothesize the following:

H3: Post-spinoff pay-performance sensitivity is positively associated with improvement in corporate governance from this transaction.

\section{Data}

Our spinoff sample is drawn primarily from the Thomson Merger and Acquisition SDC database. We identify completed spinoff transactions from the period spanning 1990 to 1997. This sample period allows us to examine the variation of corporate governance among spinoff firms without a great deal of influence from government regulations such as SOX. This period allows us to examine greater variation of governance mechanisms voluntarily implemented by firms. These spinoff transactions were later verified by searching the Lexis-Nexis database using the keywords, "spinoff", "spin off" and "spin-off". This yields 160 transactions for the initial sample. To arrive at our final sample, we exclude samples that are motivated by takeover defenses, mergers, bankruptcies and regulatory issues, spinoff firms that are tracking stock, ADRs, or in regulated industries (SIC 4900-4999 and SIC 6000-6999). We also ensure that the sample firms were not previously an equity carve-out. In addition, 17 observations have been excluded due to the absence of CEO compensation data. As a result, our final sample for the analysis is comprised of 75 firms. The profile of the sample distribution by year is reported in Table 1 .

Fiscal year stock return is used as a proxy for shareholders' wealth in estimating pay-performance elasticity. This is computed by compounding the monthly stock returns obtained from the CRSP database. To mitigate the potential impact from

Table 1 Sample distribution by year

\begin{tabular}{ll}
\hline Year & Number of Events \\
\hline 1990 & 4 \\
1991 & 2 \\
1992 & 8 \\
1993 & 8 \\
1994 & 8 \\
1995 & 11 \\
1996 & 19 \\
1997 & 15 \\
Total & 75 \\
\hline
\end{tabular}

This table shows the distribution of the 75 spinoff samples spanning from 1990 to 1997 . The sample was first identified using the Thomson SDC database. We then confirm the spinoff events by using Lexis-Nexis or the Factiva database. To ensure we obtain a clean spinoff sample, we eliminate the sample based on the following criteria: spinoff firms that are tracking stocks; spinoff motivated by takeover defenses, bankruptcies and regulatory issues; spinoffs with parent firm which are merged within one year after spinoff; spinoff firms that are in regulated industries; spinoff firms that are ADRs; spinoff firms which were previously an equity carve-out. Firms without CEO compensation data are also excluded from the sample 
outliers, firms with annual returns above 3.5 are excluded from further analysis. ${ }^{5}$ CEO compensation typically includes 4 components: (1) salary and bonus, (2) stock options, (3) restricted stock and (4) other compensation. ${ }^{6}$ Components (1) and (4) represent cash compensation whereas (2) and (3) represent equity compensation. The primary source of CEO compensation data is the Standard and Poor's ExecuComp database. The four components of CEO compensation identified above are available from ExecuComp. However, compensation data for spinoff firms prior to 1992 and firms outside the S\&P 1500 are not available. Given this fact, we manually collected compensation data from the firms' proxy statements in the Direct Edger database for those not available from ExecuComp. Of the four components of CEO compensation, stock option grants are not reported in monetary terms on the proxy statements. To ensure consistency with the data in ExecuComp, we adopted the ExecuComp modified Black-Scholes option valuation methodology to compute the monetary value for option grants in the manually-collected compensation data.

The summary statistics on the compensation and performance variables for the spinoff parent firms are presented in Panels A and B of Table 2, respectively. Year 0 in the table denotes the year of spinoff. The period reported in Table 2 includes six years in total starting from two years before spinoff (i.e., Year -2) and ending three years after spinoff (i.e., Year +3). From Panel A in Table 2, we can see that CEOs' compensation, on average, is much higher after spinoff. Comparing the components of CEO compensation from Year -2 to the post-spinoff periods (i.e., Years +1 to +3 ), CEOs receive much higher equity-based compensation (stock options and restricted stocks) after spinoff. Such CEO compensation characteristics are consistent with findings of Seward and Walsh (1996), and Jensen et al. (2004).

The summary statistics for stock returns can also be found in Panel A in Table 2. The mean stock return increases from $21.2 \%$ in Year -1 to $26.3 \%$ in Year 0 , and remains high at $25.5 \%$ in Year +1 . We have also computed summary statistics on the size of spinoffs, but they are not tabulated in order to conserve space. Following previous literature, spinoff size is defined as the market value of the spun-off unit divided by the combined market value of the post-spinoff parent and spun-off unit. ${ }^{7}$ For our sample, the mean (median) spinoff size is about $30.2 \%$ (24.3\%), generally comparable to those reported by Burch and Nanda (2003) and Ahn and Denis (2004).

For the corporate governance data, we compiled the institutional ownership data from the Thomson Reuters Institutional (13F) Holdings (formerly known as CDA/ Spectrum database). All other corporate governance variables were first obtained from the RiskMetrics Directors database (formerly known as Investor Responsibility Research Center Takeover Defense database). However, this database does not contain all the governance variables in this study (e.g., data on committee meetings are not available). Also, RiskMetrics only covers S\&P 1500 companies beginning in 1996. To complete our corporate governance dataset, we manually collected the remaining data by analysing the proxy statements included in the Direct Edger database. As Direct Edger only incorporates proxy statements commencing from 1992, this effectively limits our governance sample and the related statistical analyses to the period from 1992 to 1997. 
Table 2 Descriptive statistics

A. CEO Compensation and Performance Variables Salary and Bonus

$\begin{array}{lllllll}\text { Mean } & 1187.78 & 1213.81 & 1231.31 & 1219.18 & 1268.23 & 1335.85 \\ \text { Median } & 1077.11 & 1058.08 & 965 & 964.93 & 1148.51 & 1148.57 \\ \text { StdDev } & 844.25 & 930.27 & 998.05 & 918.12 & 888.13 & 1097.34 \\ \text { Minimum } & 141.66 & 104.80 & 36.36 & 74 & 74 & 119.88 \\ \text { Maximum } & 4109.9 & 4399.9 & 4030 & 4282.5 & 3725 & 6790 \\ \text { N } & 67 & 70 & 73 & 74 & 71 & 66\end{array}$

Stock Options

$\begin{array}{lllllll}\text { Mean } & 603.60 & 1574.27 & 1449.12 & 2311.22 & 1927.23 & 2785.05 \\ \text { Median } & 47.65 & 312.73 & 191.67 & 578.03 & 541.4 & 743.79 \\ \text { StdDev } & 924.12 & 3315.43 & 4577.57 & 6234.45 & 3082.39 & 7604.73 \\ \text { Minimum } & 0 & 0 & 0 & 0 & 0 & 0 \\ \text { Maximum } & 3666.38 & 16,068.52 & 38,000 & 40,000 & 16,172 & 54,189 \\ \text { N } & 65 & 70 & 72 & 73 & 71 & 65\end{array}$

Restricted Stock

$\begin{array}{lllllll}\text { Mean } & 110.63 & 190.13 & 210.50 & 279.55 & 340.66 & 417.54 \\ \text { Median } & 0 & 0 & 0 & 0 & 0 & 0 \\ \text { StdDev } & 314 & 1141.29 & 714.63 & 1334.87 & 1027.58 & 1607.9 \\ \text { Minimum } & 0 & 0 & 0 & 0 & 0 & 0 \\ \text { Maximum } & 1750 & 9394.34 & 3849.5 & 10,476.6 & 5520.04 & 11,800 \\ \text { N } & 67 & 70 & 73 & 74 & 71 & 66\end{array}$

Other Compensation

$\begin{array}{lllllll}\text { Mean } & 81.99 & 137.64 & 178.54 & 151.84 & 185.59 & 209.80 \\ \text { Median } & 21.39 & 32.42 & 42.31 & 47.95 & 70.43 & 46.50 \\ \text { StdDev } & 151.97 & 274.36 & 381.96 & 294.79 & 440.94 & 466.57 \\ \text { Minimum } & 0 & 0 & 0 & 0 & 0 & 0 \\ \text { Maximum } & 826.33 & 1762.82 & 2188.43 & 2004.94 & 3097.38 & 2938.93 \\ \text { N } & 68 & 70 & 73 & 74 & 71 & 66 \\ \text { Stock Return } & & & & & & \\ \text { Mean } & 0.219 & 0.212 & 0.263 & 0.255 & 0.107 & 0.239 \\ \text { Median } & 0.147 & 0.179 & 0.173 & 0.134 & 0.104 & 0.083 \\ \text { StdDev } & 0.379 & 0.410 & 0.454 & 0.578 & 0.387 & 0.930 \\ \text { Minimum } & -0.47 & -0.72 & -0.40 & -0.72 & -0.70 & -0.79 \\ \text { Maximum } & 1.59 & 1.90 & 2.05 & 3.10 & 1.50 & 6.83 \\ \text { N } & 71 & 74 & 75 & 75 & 75 & 69\end{array}$

B. Corporate Governance Variables

Component 1 - Board Structure

Percentage of Independent Directors

$\begin{array}{lllllll}\text { Mean } & 0.579 & 0.620 & 0.611 & 0.622 & 0.627 & 0.624 \\ \text { Median } & 0.615 & 0.688 & 0.667 & 0.667 & 0.646 & 0.667 \\ \text { StdDev } & 0.207 & 0.183 & 0.182 & 0.196 & 0.201 & 0.193 \\ \text { Minimum } & 0 & 0.143 & 0.143 & 0 & 0.111 & 0 \\ \text { Maximum } & 0.909 & 0.923 & 0.941 & 0.909 & 0.917 & 0.889 \\ \mathrm{~N} & 59 & 63 & 67 & 71 & 72 & 65\end{array}$


Table 2 Descriptive statistics (Continued)

\begin{tabular}{|c|c|c|c|c|c|c|}
\hline \multicolumn{7}{|c|}{ Percentage of Interlocked Directors } \\
\hline Mean & 0.039 & 0.029 & 0.025 & 0.024 & 0.024 & 0.023 \\
\hline Median & 0 & 0 & 0 & 0 & 0 & 0 \\
\hline StdDev & 0.069 & 0.052 & 0.052 & 0.054 & 0.060 & 0.061 \\
\hline Minimum & 0 & 0 & 0 & 0 & 0 & 0 \\
\hline Maximum & 0.333 & 0.2 & 0.231 & 0.308 & 0.308 & 0.333 \\
\hline $\mathrm{N}$ & 58 & 62 & 66 & 71 & 72 & 65 \\
\hline \multicolumn{7}{|c|}{ Percentage of Female Directors } \\
\hline Mean & 0.074 & 0.080 & 0.079 & 0.077 & 0.080 & 0.089 \\
\hline Median & 0.083 & 0.083 & 0.083 & 0.083 & 0.083 & 0.091 \\
\hline StdDev & 0.075 & 0.068 & 0.070 & 0.068 & 0.071 & 0.072 \\
\hline Minimum & 0 & 0 & 0 & 0 & 0 & 0 \\
\hline Maximum & 0.3 & 0.231 & 0.25 & 0.273 & 0.3 & 0.273 \\
\hline \multirow[t]{2}{*}{$N$} & 59 & 63 & 67 & 71 & 72 & 65 \\
\hline & Year-2 & Year-1 & Year 0 & Year +1 & Year +2 & Year +3 \\
\hline \multicolumn{7}{|l|}{ CEO Power } \\
\hline Mean & 1.32 & 1.38 & 1.35 & 1.37 & 1.46 & 1.32 \\
\hline Median & 1 & 1 & 1 & 1 & 1.5 & 1 \\
\hline StdDev & 0.68 & 0.68 & 0.71 & 0.73 & 0.79 & 0.74 \\
\hline Minimum & 0 & 0 & 0 & 0 & 0 & 0 \\
\hline Maximum & 3 & 3 & 3 & 3 & 3 & 3 \\
\hline $\mathrm{N}$ & 59 & 63 & 66 & 70 & 70 & 63 \\
\hline
\end{tabular}

Component 2 - Committee Independence

Percentage of Independent Directors in Audit Committee

$\begin{array}{lllllll}\text { Mean } & 0.82 & 0.83 & 0.84 & 0.85 & 0.87 & 0.84 \\ \text { Median } & 1 & 1 & 1 & 1 & 1 & 1 \\ \text { StdDev } & 0.23 & 0.22 & 0.19 & 0.24 & 0.23 & 0.26 \\ \text { Minimum } & 0 & 0 & 0.33 & 0 & 0 & 0 \\ \text { Maximum } & 1 & 1 & 1 & 1 & 1 & 1 \\ \mathrm{~N} & 57 & 61 & 64 & 70 & 71 & 63\end{array}$

Percentage of Independent Directors in Compensation Committee

$\begin{array}{lllllll}\text { Mean } & 0.80 & 0.83 & 0.85 & 0.86 & 0.87 & 0.88 \\ \text { Median } & 0.8 & 1 & 1 & 1 & 1 & 1 \\ \text { StdDev } & 0.24 & 0.26 & 0.26 & 0.26 & 0.25 & 0.22 \\ \text { Minimum } & 0 & 0 & 0 & 0 & 0 & 0 \\ \text { Maximum } & 1 & 1 & 1 & 1 & 1 & 1 \\ \text { N } & 57 & 59 & 61 & 69 & 69 & 61\end{array}$

Component 3 - Board and Committee Meetings

Board Meetings

$\begin{array}{lllllll}\text { Mean } & 7.71 & 7.31 & 8.16 & 7 & 7.14 & 7.18 \\ \text { Median } & 8 & 7 & 8 & 7 & 6 & 6 \\ \text { StdDev } & 2.68 & 2.8 & 3 & 2.22 & 3.1 & 2.54 \\ \text { Minimum } & 1 & 1 & 1 & 1 & 1 & 1 \\ \text { Maximum } & 16 & 15 & 18 & 12 & 24 & 18 \\ \text { N } & 58 & 64 & 68 & 68 & 63 & 61\end{array}$


Table 2 Descriptive statistics (Continued)

\begin{tabular}{|c|c|c|c|c|c|c|}
\hline \multicolumn{7}{|c|}{ Audit Committee Meetings } \\
\hline Mean & 3.38 & 3.46 & 3.26 & 3.35 & 3.22 & 3.48 \\
\hline Median & 3 & 3 & 3 & 3 & 3 & 3 \\
\hline StdDev & 1.40 & 1.43 & 1.57 & 1.47 & 1.30 & 1.78 \\
\hline Minimum & 1 & 0 & 0 & 0 & 1 & 1 \\
\hline Maximum & 7 & 7 & 8 & 8 & 7 & 11 \\
\hline $\mathrm{N}$ & 58 & 63 & 66 & 66 & 64 & 61 \\
\hline \multicolumn{7}{|c|}{ Compensation Committee Meetings } \\
\hline Mean & 4.63 & 4.92 & 4.79 & 4.45 & 4.47 & 4.39 \\
\hline Median & 4 & 5 & 5 & 4 & 4 & 4 \\
\hline StdDev & 2.02 & 1.97 & 2.36 & 1.92 & 2.13 & 2.05 \\
\hline Minimum & 1 & 1 & 0 & 1 & 1 & 1 \\
\hline Maximum & 9 & 9 & 13 & 9 & 13 & 10 \\
\hline $\mathrm{N}$ & 56 & 59 & 63 & 66 & 62 & 59 \\
\hline \multicolumn{7}{|c|}{ Component 4 - Institutional Ownership } \\
\hline Mean & 0.491 & 0.521 & 0.538 & 0.567 & 0.573 & 0.580 \\
\hline Median & 0.535 & 0.568 & 0.571 & 0.603 & 0.633 & 0.632 \\
\hline StdDev & 0.186 & 0.195 & 0.198 & 0.199 & 0.190 & 0.198 \\
\hline Minimum & 0 & 0.059 & 0.049 & 0.044 & 0.039 & 0.057 \\
\hline Maximum & 0.791 & 0.935 & 1 & 0.993 & 0.846 & 0.900 \\
\hline$N$ & 72 & 72 & 73 & 73 & 70 & 64 \\
\hline
\end{tabular}

Descriptive statistics of the CEO compensation components, performance variable and spinoff size for the spinoff sample from two years before spinoff to three years after spinoff. Year 0 denotes the year of spinoff event. The spinoff parents' CEO compensation statistics, performance statistics and governance measures statistics are shown in Section A and B respectively. The 4 components of CEO compensation: salary and bonus, option grants, restricted stocks, and other compensation are obtained from the Execucomp database or company proxy statement from the Direct Edger database in cases where the data is not available from Execucomp. CEO compensation is denoted in thousands of dollars. Stock return refers to the annual stock return for the firm's fiscal year and is computed by compounding the monthly returns obtained from the CRSP database. Stock returns are denoted in percentages. Percentage of independent directors (directors who do not have business and family ties with the firm and have not been employed by the firm for the last 3 years), percentage of interlocked directors (outside directors with their companies' boards served by an inside officer of the firm), and percentage of female directors are expressed as a fraction of total board members. CEO Power is a score formed by adding three indicator variables: CEO is the chair of the board, CEO is the founder of the firm and CEO is the only insider of the board. Board and committee meetings are the number of board, audit committee and compensation committee meetings held per year. Percentage of independent directors in audit, compensation and nominating are expressed as a fraction of the total committee members. Institutional investors' ownership is expressed as a fraction of total shares outstanding. Institutional investors' share ownership is obtained from Thomson Reuters Institutional (13F) Holdings (formerly known as CDA/Spectrum database). All other governance variables are obtained from the RiskMetrics Directors database (formerly known as Investor Responsibility Research Center (IRRC) Takeover Defense database) or directly from the proxy statements in the Direct Edger database. Variation in sample size is due to data availability

\section{Measures of corporate governance}

We examine four broad components of corporate governance: board structure, committee independence, board and committee activities, and institutional ownership. Variables included in each component are drawn from the previous literature.

\section{Board structure}

As indicated by Fama and Jensen (1983), the board of directors is the apex of corporate governance. The characteristics of board members as a whole are crucial to the 
effectiveness of a firm's governance. The first variable we include in this component is the percentage of outside independent directors on the board. Independent outside directors are directors who do not have outside business or a family relationship with the firm, and have not been employed by the firm in the previous 3 years. As indicated by prior studies (Rosenstein and Wyatt 1990; Karamanou and Vafeas 2005; Cornett et al. 2008; Chhaochharia and Grinstein 2009; Nguyen and Nielsen 2010), independent outside directors can serve as effective monitors of the company as they are not influenced by a firm's management and can thus exert greater pressure on management due to more independent views as compared to inside directors. ${ }^{8}$ Armstrong et al. (2014) document that the proportion of independent directors on the board is positively associated with transparency. It thus follows that a higher percentage of outside independent directors on the board represents more effective governance.

The next variable included in this component is the percentage of interlocked directors. Two directors are considered "interlocked" when one director is serving as a board member of the other director's company. The close relationship between interlocked directors can impair board independence by mutually influencing each other's choices for their personal advantage, thereby detracting from the boards' monitoring role. Thus, a higher percentage of interlocked directors indicates poor corporate governance. This view is expressed by a number of corporate governance studies (Hallock 1997; Core et al. 1999; Larcker et al. 2005; Bizjak et al. 2009; Dah and Frye 2017), along with regulators and professional bodies (the Securities and Exchange Commission and the National Association of Corporate Directors).

As a measure of board diversity, we use the percentage of female directors. Morck (2008) states that a heterogeneous board can eliminate directors' tendencies to submit to authority, such as the CEO, resulting in broader perspectives and lower levels of groupthink. Lavy and Schlosser (2011) suggest that having a diverse board can promote peer monitoring between genders in the decision making process. Furthermore, Carter et al. (2003), Adams and Ferreira (2009), García-Meca et al. (2015), and Green and Homroy (2018) document that board diversity, proxied by the percentage of female directors, promotes better monitoring and leads to improved firm performance. Additionally, a recent study by Schwartz-Ziv (2017) finds that boards are more active when more than 3 women are present in board meetings; boards with at least 3 directors of each gender are $79 \%$ more active; and underperforming CEOs are likely to be replaced by more gender-balanced boards.

The final variable included in this component is CEO Power. CEO Power is a measure of structural power which is a composite score based on three indicator variables: the CEO being the chairman of the board, the CEO being the founder of the firm, and the CEO being the only insider on the board. Thus, the range of this composite score varies from 0 to 3 , where a higher score represents stronger CEO influence on the board and therefore on corporate decisions. These three measures of CEO Power have been used previously in the literature (Adams et al. 2005; Cheng 2008; Liu and Jiraporn 2010). We support the contention from previous studies, which generally find that CEO dominance hampers corporate governance. Powerful CEOs are associated with lower Tobin's Q in firm and accounting profitability (Bebchuk et al. 2011), higher variability in a firm's performance (Adams et al. 2005), higher cost of debt in firms (Liu and Jiraporn 2010), rigged incentive pay by inducing boards to shift weight to better performance measures (Morse et al. 2011), stronger association between the CEO's 
personal leverage and the firm's leverage (Korkeamäki et al. 2017), and difficulty of removal by the board (Morck et al. 1989).

\section{Board committee Independence}

For this component, we examine the independence of two important board committees: the audit and compensation committees appointed by a board. Klein (1998) argues that the audit committee can mitigate agency problems by ensuring the presence of proper internal controls in the organization; whereas the compensation committee does so by designing incentive schemes which promote interest alignment among shareholders and managers. Armstrong et al. (2014) also find that audit committee independence is associated with higher-quality financial reporting and stronger commitment to internal controls. Following Klein (1998), Anderson et al. (2004), Uzun et al. (2004), and Guo and Masulis (2015), we use the percentage of independent directors on these two committees as a measure of committee independence. The intuition is straightforward: just as more independent directors on a board enhance the board's monitoring function, so should their presence on these committees. Klein (2002), Anderson et al. (2004) and Vafeas (2003) provide consistent evidence for this view.

\section{Board and committee meetings}

The performance and effectiveness of a board and its committees are related to the work carried out by the board and committee members. Following Vafeas (1999), Beasley et al. (2000), and Karamanou and Vafeas (2005), we use the number of board and committee meetings to measure the effort and time spent by board and committee members. Active boards and committees meet more often and thus increase the amount of time spent on monitoring efforts, consequently improving governance (Conger et al. 1998; Anderson et al. 2004; Karamanou and Vafeas 2005; Andres and Vallelado 2008; Chou et al. 2013).

\section{Institutional ownership}

Jensen (1993) suggests that institutional investors have both the incentive and the ability to actively monitor management to safeguard their financial interests in the firm. In line with prior studies such as Core et al. (1999), Hartzell and Starks (2003), Yun (2009), Boone and White (2015), Crane et al. (2016), and Bena et al. (2017), we use the level of institutional ownership as a measure of external monitoring.

Descriptive statistics for the 10 corporate governance variables comprising the four governance components discussed above are displayed in Panel B of Table 2. With regards to board structure, the mean (median) percentage of independent directors after spinoff increases from $57.7 \%(61.5 \%)$ in Year -2 to $62.4 \%(66.7 \%)$ in Year +3 . Such an increase is consistent with the findings by Seward and Walsh (1996) and Ahn and Walker (2007). Similarly, the percentage of interlocked directors and the percentage of female directors have improved after spinoff. Comparing the mean for these two variables in Year -2 with Year +3 , the mean percentage of interlocked directors dropped from $3.9 \%$ to $2.3 \%$, and the mean percentage of female directors increased from $7.4 \%$ to $8.9 \%$. Finally, there is little change in CEO Power, as both the mean and median scores are virtually unchanged from Year -2 to Year +3 . As a whole, the 
evidence from the summary statistics broadly suggests that board structure for parent firms improves after spinoff.

In terms of committee independence, both audit and compensation committees become more independent after spinoff. From Year -2 to Year +3 , the mean percentage of independent directors in audit and compensation committees has increased by 2 percentage points and 8 percentage points, respectively. In fact, the average percentage of independent directors among these two committees are $80 \%$ or above throughout the event years. Taken together, spinoff firms on average have very independent board committees, and the level of independence increases after spinoff. Our findings are consistent with those of Seward and Walsh (1996), suggesting that the majority of the members in compensation committees are outside directors.

With regards to board and committee meetings, the median board meets 6 to 8 times per year; the median audit committee meets 3 times per year; and the median compensation committee meets 4 to 5 times per year. These observations are consistent with Vafeas (1999) and Karamanou and Vafeas (2005). In addition, the average board and compensation committee meet slightly more during Year -1 to Year 0 . This is likely related to the occurrence of the spinoff event. With the exception of the audit committee, the mean board and compensation committee meetings are reduced slightly from Year -2 to Year +3 .

Institutional investors, on average, own more equity after spinoff: the mean (median) ownership increases from $49.1 \%$ (53.5\%) in Year -2 to 58\% (63.2\%) in Year +3 . The increase in institutional ownership after spinoff indicates an improvement in external monitoring.

Overall, the statistics suggest that the general governance structure improves after spinoff, consistent with our conjecture.

\section{Interest alignment and spinoff}

\section{Pay-performance sensitivity before and after spinoff}

The purpose of this study is to examine whether spinoff improves CEO-shareholder interest alignment. We first examine the pay-performance sensitivity for spinoff firms before and after spinoff by estimating the following model:

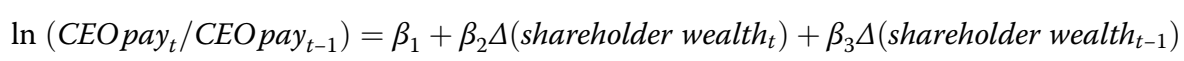

Equation (1) is based on the pay-performance sensitivity model by Hall and Liebman (1998) and Murphy (1999), which tests the association between the change in both contemporaneous and lagged shareholder wealth on the change in CEO compensation. ${ }^{9}$ The dependent variable is the first difference of CEO compensation. Consistent with prior compensation literature, we use two alternate measures of CEO compensation: the first is cash compensation consisting of salary and bonus only, and the second is total compensation consisting of salary and bonus, stock options and restricted stock grants, and other compensation.

The independent variables are the changes in contemporaneous and lagged shareholder wealth. Shareholder wealth is proxied by the annual fiscal year stock returns. We estimate Model (1) at Year -1 , Year +1 and Year +3 . These three periods allow us to gain insight as to whether pay-performance sensitivity of spinoff parent firms 
Table 3 Yearly pay-performance elasticity regressions: stock returns

\begin{tabular}{|c|c|c|c|}
\hline & Year -1 & Year +1 & Year +3 \\
\hline \multicolumn{4}{|c|}{ Panel A - Dependent Variable: Log Difference in Salary and Bonus } \\
\hline \multirow[t]{2}{*}{ Intercept (b1) } & -0.038 & 0.007 & -0.015 \\
\hline & $(-0.58)$ & $(0.11)$ & $(-0.31)$ \\
\hline \multirow[t]{2}{*}{$R t n_{t}(b 2)$} & 0.079 & 0.007 & $0.270^{* * *}$ \\
\hline & $(0.64)$ & $(0.07)$ & $(4.12)$ \\
\hline \multirow[t]{2}{*}{$\operatorname{Rtn}_{t-1}(b 3)$} & 0.19 & 0.142 & 0.135 \\
\hline & $(1.55)$ & $(1.55)$ & $(1.12)$ \\
\hline N & 66 & 73 & 65 \\
\hline$R^{2}$ & 0.03 & 0.022 & 0.16 \\
\hline \multicolumn{4}{|c|}{ Panel B - Dependent Variable: Log Difference in Total CEO Compensation } \\
\hline \multirow[t]{2}{*}{ Intercept (b1) } & $0.641^{* * *}$ & $0.44^{* * *}$ & $0.63^{* * *}$ \\
\hline & $(4.71)$ & $(3.88)$ & $(6.76)$ \\
\hline \multirow[t]{2}{*}{$R \operatorname{tn} t(b 2)$} & -0.173 & $0.38^{* *}$ & $0.28^{* *}$ \\
\hline & $(-0.68)$ & $(1.98)$ & $(2.09)$ \\
\hline \multirow[t]{2}{*}{$R t n_{t-1}(b 3)$} & -0.127 & $0.72^{* *}$ & $0.64^{* *}$ \\
\hline & $(-0.44)$ & $(2.23)$ & $(2.47)$ \\
\hline N & 65 & 72 & 64 \\
\hline$R^{2}$ & 0.01 & 0.186 & 0.122 \\
\hline \multicolumn{4}{|c|}{ 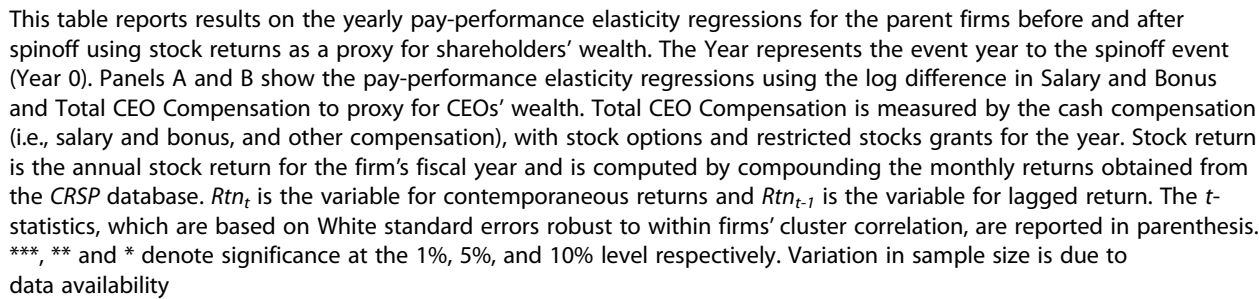 } \\
\hline
\end{tabular}

improves immediately, and in the long term after spinoff. Improved pay-performance sensitivity coefficients (i.e., $\beta_{2}$ and $\beta_{3}$ ) after spinoff would suggest better interest alignment whereas a deteriorated trend in these coefficients would suggest risk aversion.

Table 3 shows the results of the yearly pay-performance sensitivity regressions for Year -1 , Year +1 and Year +3 . Panel A uses salary and bonus as a proxy for a CEO's wealth whereas Panel $\mathrm{B}$ uses total compensation. The $R$-squares for all specifications tend to be low, consistent with the extant pay-performance sensitivity literature (Hall and Liebman 1998; Murphy 1999; and Conyon and Murphy 2000). In spite of this, the $R$-square for the post spinoff regressions are much higher than pre-spinoff counterparts. From the perspective of precision, this result suggests that post-spinoff pay-performance sensitivity coefficients are considered better than those in the pre-spinoff year.

As can be seen from Panel A in Table 3, CEO's cash compensation (salary and bonus only) is not statistically significantly related to firm performance, except for Year +3 , in which the coefficient on contemporaneous stock returns is positive and significant at the $1 \%$ level. Thus, there is some evidence of improved interest alignment in the longer horizon after spinoff.

The results in Panel B where CEO's total compensation is used present much stronger evidence that spinoffs improve interest alignment. Specifically, CEO total 
compensation before spinoff is not significantly related to shareholders' wealth. But for both Year +1 and Year +3 , both the contemporaneous and lagged pay-performance sensitivity coefficients are positive and significant at the $5 \%$ level. Interpreting this finding with the corresponding post spinoff estimates in Panel A, stock options and restricted stocks granted to the CEO after spinoff seem to improve interest alignment. This is consistent with the CEO compensation literature findings that equity compensation is a key component in driving the total pay-performance sensitivity. This is also consistent with the notion that the use of equity-based compensation promotes a closer interest alignment between a CEO and shareholders (Jensen and Murphy 1990; Hall and Liebman 1998; Murphy 1999; Conyon and Murphy 2000).

The key insight from the yearly regressions indicates that spinoff improves pay-performance sensitivity. This finding is more apparent in cases in which total CEO compensation is used. This evidence also provides a first support to our interest alignment hypothesis.

\section{Panel pay-performance sensitivity analysis}

Having established the trend that spinoff improves pay-performance, we next proceed to formally testing whether the improvement in interest alignment is statistically significant (i.e., hypothesis $\mathrm{H1}$ ). We perform our analysis by using the following panel regression model:

$$
\begin{aligned}
& \ln \left(\text { CEOpay }_{t} / \text { CEOpay }_{t-1}\right)=\beta_{1}+\beta_{2} \Delta\left(\text { shareholderwealth }_{t}\right)+\beta_{3} \Delta\left(\text { shareholderwealth }_{t-1}\right) \\
& +\beta_{4} S p D+\beta_{5} \times S p D \times \Delta\left(\text { shareholderwealth }_{t}\right)+\beta_{6} \times S p D \times \Delta\left(\text { shareholderwealth }_{t-1}\right)
\end{aligned}
$$

$S p D$ is a dummy variable which takes a value of 0 to indicate a pre-spinoff year and a value of 1 to indicate a post-spinoff year. We first estimate Equation (2) using one pre-spinoff year (Year -1$)$ and one post-spinoff year $($ Year +1$)$, and to ensure robustness and persistence of the results in the long run, we also repeat the test by combining the Year -1 and a sample composed of all the post spinoff event years (i.e., Year +1 to Year $+3)$.

The key variables of interest in this model are the interaction terms: $S p D \times \Delta$ (shareholder wealth $h_{t}$ and $S p D \times \Delta\left(\right.$ shareholder wealth $\left.h_{t-1}\right)$. Both variables capture the change in pay-performance sensitivity before and after the spinoff event. If spinoffs improve CEO contracting efficiency according to the interest alignment hypothesis, we expect the coefficients of these two interaction terms (i.e., $\beta_{5}, \beta_{6}$ ) to be positive and significant. Alternatively, the risk aversion hypothesis will predict the opposite.

Table 4 displays the results for the panel pay-performance sensitivity regressions. Panel A reports the panel regressions including only the pre-spinoff year (Year -1$)$ and the immediate post spinoff year $($ Year +1$)$, whereas Panel B extends the sample by combining two additional post spinoff years (i.e., Year +2 and Year +3 ) in order to capture the long-run impact.

We can see from the short-run regression results in Panel A of Table 4, the interaction terms in the cash compensation model are insignificant at the conventional significance levels, but the interaction terms in the total compensation model are both statistically significant at the $5 \%$ level. These results are consistent with yearly regressions in Table 3, suggesting that in the short run, CEO total compensation, with equity pay included, is much more sensitive to firm performance after spinoff.

The long-run regression results in Panel B of Table 4 paint a very similar picture to that in the short run: spinoffs do not bring about any higher sensitivity between CEO 
Table 4 Pay-performance elasticity panel regressions

\begin{tabular}{|c|c|c|c|c|}
\hline & \multicolumn{2}{|c|}{ Dependent Variable: The Log Difference in } & \multicolumn{2}{|c|}{ Dependent Variable: The Log Difference in } \\
\hline & Salary and Bonus & Total Compensation & Salary and Bonus & Total Compensation \\
\hline \multicolumn{3}{|c|}{ Panel A - Pay Performance Elasticity Regressions } & \multicolumn{2}{|c|}{$\begin{array}{l}\text { Panel B - Panel Pay-Performance } \\
\text { Elasticity Regressions with Long Run } \\
\text { Post Spinoff Sample }\end{array}$} \\
\hline \multirow[t]{2}{*}{ Intercept (b1) } & -0.03 & $0.64^{* * *}$ & -0.04 & $0.64^{* * *}$ \\
\hline & $(-0.58)$ & $(4.7)$ & $(-0.59)$ & $(4.8)$ \\
\hline \multirow[t]{2}{*}{$R t n_{t}(b 2)$} & 0.07 & -0.17 & 0.08 & -0.17 \\
\hline & $(0.63)$ & $(-0.68)$ & $(0.64)$ & $(-0.69)$ \\
\hline \multirow[t]{2}{*}{$R t n_{t-1}(b 3)$} & 0.19 & -0.12 & 0.19 & -0.13 \\
\hline & $(1.54)$ & $(-0.44)$ & $(1.56)$ & $(-0.44)$ \\
\hline \multirow[t]{2}{*}{$S p D(b 4)$} & 0.05 & -0.2 & 0.05 & -0.06 \\
\hline & $(0.47)$ & $(-1.3)$ & $(0.66)$ & $(-0.45)$ \\
\hline \multirow[t]{2}{*}{$S p D \times \operatorname{Rtn}_{t}(b 5)$} & -0.07 & $0.55^{*}$ & 0.03 & $0.47^{*}$ \\
\hline & $(-0.44)$ & $(1.68)$ & $(0.22)$ & $(1.67)$ \\
\hline \multirow[t]{2}{*}{$S p D \times R t n_{t-1}(b 6)$} & -0.05 & $0.85^{* *}$ & -0.12 & $0.62^{*}$ \\
\hline & $(-0.31)$ & $(1.97)$ & $(-0.94)$ & $(1.87)$ \\
\hline N & 139 & 137 & 274 & 271 \\
\hline$R^{2}$ & 0.03 & 0.13 & 0.02 & 0.09 \\
\hline
\end{tabular}

This table reports results on the panel pay-performance elasticity regression for the pre- and post-spinoff parent. Panel A shows the panel regression results combines one pre-spinoff year (Year -1 ) sample and one post-spinoff year (Year +1 ) sample. Panel B shows the panel regression estimation combines the same pre-spinoff sample with three post-spinoff years (Year +1 to Year +3 ) sample. Parents firms' sample is taken for both pre- and post-spinoff period. Both the log difference in salary and bonus and total CEO compensation are used as proxy for the dependent variable as indicated in the table. $S p D$ is an indicator variable which takes a value of 0 before spinoff and 1 otherwise. All other variables are previously defined in Table 3 . In both panels, $t$-statistics, which are based on White standard errors robust to within firms' cluster correlation, are reported in parenthesis. ${ }^{* *},{ }^{* *}$ and ${ }^{*}$ denote significance at the $1 \%, 5 \%$, and $10 \%$ level respectively. Variation in sample size is due to data availability

cash compensation and firm performance, but do improve CEO total pay-performance sensitivity in the long run. Specifically, the interaction terms remain insignificant in the cash compensation model, and are positive and significant at the $5 \%$ level in the total compensation model. These findings are consistent with the yearly regression results observed in Table 3.

Overall, our findings in Table 4 suggest that, in both the short run (one year after spinoff) and the long run (three years after spinoff), there is a significant improvement in the association between the annual change in total CEO pay and market-based annual shareholder wealth creation. Again, equity compensation plays a major role in improving interest alignment for spinoff firms. Our results from both Tables 3 and 4 support the interest alignment. This finding complements the spinoff value gain explanation advanced by Hite and Owers (1983) and Schipper and Smith (1983); both of these studies suggest that spinoff creates value by improving contracting efficiency. In addition, our empirical evidence supports the theoretical model from Aron (1991), suggesting that spinoff allows the firm to write and enforce performance-based incentive contracts in a less costly manner. From a broader perspective, our results are consistent with the view from a strand of spinoff studies (Seward and Walsh 1996; Burch and Nanda 2003; and Ahn and Walker 2007) which suggest that spinoff creates value by mitigating agency costs present in multi-divisional organizations. 


\section{Governance and interest alignment of spinoff firms}

\section{The relationship of corporate governance to interest alignment of spinoff firms}

In this section, we examine the effect of corporate governance on interest alignment. This is a natural extension of our analyses above as corporate governance aims to foster interest alignment between shareholders and managers. To do so, we modify Equation (2) with the inclusion of governance variables:

$$
\begin{aligned}
& \ln \left(\text { CEOpay }_{t} / \text { CEOpay }_{t-1}\right)=\beta_{1}+\beta_{2} \Delta\left(\text { shareholderwealth }_{t}\right)+\beta_{3} \Delta\left(\text { shareholderwealth }_{t-1}\right) \\
& +\beta_{4} \times S p D \times \Delta\left(\text { shareholderwealth }_{t}\right)+\beta_{5} \times S p D \times \Delta\left(\text { shareholderwealth }_{t-1}\right)+\beta_{6} R C G \\
& +\beta_{7} S p D+\beta_{8} \times S p D \times \Delta\left(\text { shareholderwealth }_{t}\right) \times R C G+\beta_{9} \times S p D \times \Delta\left(\text { shareholderwealt }_{t-1}\right) \\
& \times R C G+\text { IndustryDummies }+ \text { YearDummies }
\end{aligned}
$$

The new variable included in Equation (3) is $R C G$, which represents the rank of each governance component (board structure, committee independence, board and committee meetings, and institutional ownership) and the overall rank averaged across the ranks of the four components. The use of this rank makes it easier to compare the effect of each corporate governance component and to assess the impact of a firm's overall governance. Accordingly, in the five models we present in Table 5, the governance rank variable $R G C$ denotes the rank on each of the four components as discussed in Section 3.1 and the rank of the aggregated governance components. Briefly, Component 1 is the rank of board structure, which includes the percentage of outside independent directors, the percentage of interlocked directors and CEO Power; Component 2 is the rank of committee independence, which comprises the percentage of outside independent directors in compensation and audit committees; Component 3 is the rank of board and committee activities, which consists of the number of board meetings per year, and the number of audit and compensation committee meetings per year; Component 4 is the rank of the percentage of shares owned by institutional investors; and Component Total is the averaged rank of the four components above.

The key explanatory variables in Equation (3) are the $R C G$ variable and the three-way interaction terms. Equation (3) is estimated with panel data, spanning from Year -1 to Year +3 . If corporate governance is related to the improvement in interest alignment as hypothesized, the coefficient $\beta_{5}$ is expected to be positive and significant. In addition, if the interest alignment for the stronger governance group is more pronounced as hypothesized, the coefficients $\beta_{8}, \beta_{9}$ or both are expected to be positive and significant. Table 5 reports the regressions results.

As can be seen in Table 5, the coefficients for RCG on all four corporate governance components as well as the overall governance score are positive. Moreover, the coefficients on board structure, institutional ownership, and the overall governance score are statistically significant at $10 \%$ or better. These results are generally consistent with Hartzell and Starks (2003), who document a positive association between institutional ownership and CEO pay-performance sensitivity, and Seward and Walsh (1996), who argue that spinoffs facilitate the implementation of effective governance and control mechanisms.

For the three-way interaction terms, nearly all the coefficients are insignificant at the conventional levels. The only exception is the coefficient on the interaction 
Table 5 Corporate governance \& pay-performnace elasticity regressions

\begin{tabular}{|c|c|c|c|c|c|}
\hline & \multicolumn{5}{|c|}{ Dependent Variable: Log Difference in Total Compensation } \\
\hline & $\begin{array}{l}\text { Component } 1 \\
\text { Board Structure }\end{array}$ & $\begin{array}{l}\text { Component } 2 \\
\text { Committee } \\
\text { Independence } \\
\end{array}$ & $\begin{array}{l}\text { Component } 3 \text { Board } \\
\text { and Committee Meetings }\end{array}$ & $\begin{array}{l}\text { Component } 4 \\
\text { Institutional } \\
\text { Ownership } \\
\end{array}$ & $\begin{array}{l}\text { Component } \\
\text { Total }\end{array}$ \\
\hline \multirow{2}{*}{$\begin{array}{l}\text { Intercept } \\
\text { (b1) }\end{array}$} & $0.634^{* *}$ & $0.955^{* * *}$ & $0.803^{* * *}$ & $0.657^{* * *}$ & 0.472 \\
\hline & $(2.21)$ & $(3.92)$ & (3.19) & $(3.21)$ & $(1.45)$ \\
\hline \multirow[t]{2}{*}{$R \operatorname{tn} t_{t}(b 2)$} & -0.102 & 0.010 & -0.046 & -0.156 & 0.039 \\
\hline & $(-0.42)$ & $(0.04)$ & $(-0.15)$ & $(-0.67)$ & $(0.14)$ \\
\hline \multirow{2}{*}{$R_{t n_{t-1}}$ (b3) } & -0.139 & -0.063 & -0.226 & -0.095 & 0.057 \\
\hline & $(-0.53)$ & $(-0.24)$ & $(-0.79)$ & $(-0.35)$ & $(0.21)$ \\
\hline \multirow{2}{*}{$\begin{array}{l}S p D \times R t n_{t} \\
\text { (b4) }\end{array}$} & 0.155 & 0.031 & 0.338 & 0.352 & 0.252 \\
\hline & $(0.38)$ & $(0.09)$ & $(0.73)$ & $(1.2)$ & $(0.52)$ \\
\hline \multirow{2}{*}{$\begin{array}{l}S p D \times R t n_{t-1} \\
\text { (b5) }\end{array}$} & $0.732^{*}$ & 0.445 & $1.077^{* * *}$ & $0.620^{* *}$ & 0.771 \\
\hline & $(1.86)$ & $(1.27)$ & $(2.67)$ & $(2.06)$ & $(1.56)$ \\
\hline \multirow[t]{2}{*}{$R C G(b 6)$} & $0.002^{*}$ & 0.000 & 0.002 & $0.007^{* *}$ & $0.001^{*}$ \\
\hline & $(1.75)$ & $(0.18)$ & $(1.41)$ & (2.38) & $(1.81)$ \\
\hline \multirow[t]{2}{*}{$S p D(b 7)$} & $-0.291^{* *}$ & $-0.224^{*}$ & $-0.28^{*}$ & -0.203 & -0.172 \\
\hline & $(-2.33)$ & $(-1.88)$ & $(-1.86)$ & $(-1.48)$ & $(-1.39)$ \\
\hline \multirow{2}{*}{$\begin{array}{l}S p D \times R C G \\
\times R t n_{t}(b 8)\end{array}$} & 0.001 & 0.003 & -0.001 & -0.001 & 0.000 \\
\hline & $(0.49)$ & $(0.82)$ & $(-0.36)$ & $(-0.39)$ & $(-0.31)$ \\
\hline \multirow{2}{*}{$\begin{array}{l}S p D \times R C G \\
\times R t n_{t-1}(b 9)\end{array}$} & -0.002 & -0.002 & $-0.006^{* *}$ & -0.008 & -0.002 \\
\hline & $(-0.87)$ & $(-0.74)$ & $(-2.11)$ & $(-1.35)$ & $(-1.32)$ \\
\hline $\begin{array}{l}\text { Industry } \\
\text { Dummies }\end{array}$ & Included & Included & Included & Included & Included \\
\hline Year Dummies & Included & Included & Included & Included & Included \\
\hline N & 257 & 247 & 233 & 262 & 223 \\
\hline$R^{2}$ & 0.211 & 0.211 & 0.194 & 0.213 & 0.193 \\
\hline
\end{tabular}

This table reports the coefficients on the panel pay-performance elasticity regression interacted with a composite corporate governance score, $R C G$, for the pre-spinoff parent in Year -1 and the post-spinoff parent firms from Year +1 to Year +3 . The dependent variable for all regressions is the first difference in the log of total CEO compensation. Shareholder wealth is measured by stock return. $R C G$ is the sum of the ranked corporate governance variable in each of the 4 different components of corporate governance: board structure (Component 1), committee independence (Component 2), board and committee meetings (Component 3) and institutional ownership (Component 4). A higher value RCG denotes stronger governance. Industry dummies are indicator variables denoting the industry of sample firms in 4-digit SIC codes. Other variables are previously defined. The $t$-statistics, which are based on White standard errors robust to within firms' cluster correlation, are reported in parenthesis. ${ }^{* * *}$, ** and ${ }^{*}$ denote significance at the $1 \%, 5 \%$, and $10 \%$ level respectively. Variation in sample size is due to data availability

term with board and committee meetings (Component 3), which is negative and statistically significant at $5 \%$. This suggests that firms with more board and committee activities are associated with weaker interest alignment. This is broadly consistent with findings from Vafeas (1999) that firm value is inversely associated with board meetings.

The change in governance and post-spinoff interest alignment

Empirical results from the previous section have provided some evidence that governance structure present in spinoff firms is associated with interest alignment. To sharpen our results, we examine the effect of the change in corporate governance on CEO pay-performance sensitivity by estimating the following model: 


$$
\begin{aligned}
& \ln \left(\text { CEOpay }_{t} / \text { CEOpay }_{t-1}\right)=\beta_{1}+\beta_{2} \Delta\left(\text { shareholderwealt }_{t}\right)+\beta_{3} \Delta\left(\text { shareholderwealth }_{t-1}\right) \\
& +\beta_{4} \Delta R C G+\beta_{5} \times \Delta\left(\text { shareholderwealt }_{t}\right) \times \Delta R C G+\beta_{6} \times \Delta\left(\text { shareholderwealth }_{t-1}\right) \times \Delta R C G
\end{aligned}
$$

The $\triangle R C G$ variable in Equation (4) is the rank change for each of the four governance components as well as the overall governance score. To construct each $\triangle R C G$, we first obtain the average of a corporate governance variable rank in Year - 2 and Year 1 , and then the average of the same variable ranks in Year +1 to Year +3 . We obtain each $\triangle R C G$ by subtracting the post-spinoff average rank from the pre-spinoff rank for each corporate governance variable. A higher $\triangle R C G$ value represents a stronger governance improvement. If spinoff firms' post spinoff interest alignment is associated with the change in corporate governance as hypothesized, the coefficients $\beta_{5}, \beta_{6}$ or both are expected to be positive and significant.

The results for this analysis are displayed in Table 6. The coefficient for $\operatorname{Rtn}_{t} \times \Delta R C G$ for committee independence (Component 2) and board and committee activities (Component 3 ) are positive and significant at the $10 \%$ level. In other words, improving committee independence and board and committee activities can reduce agency problems by promoting interest alignment of firms after spinoff. This result is consistent with the view from Klein (1998) that committee independence is important regarding their roles; and the argument from Conger et al. (1998) that frequency of board meetings is a factor in board effectiveness. From a broader standpoint, it also supports the contention

\begin{tabular}{|c|c|c|c|c|c|}
\hline & \multicolumn{5}{|c|}{ Dependent Variable: Log Difference in Total Compensation } \\
\hline & $\begin{array}{l}\text { Component } 1 \\
\text { Board Structure }\end{array}$ & $\begin{array}{l}\text { Component } 2 \\
\text { Committee } \\
\text { Independence }\end{array}$ & $\begin{array}{l}\text { Component } 3 \\
\text { Board and } \\
\text { Committee Meetings }\end{array}$ & $\begin{array}{l}\text { Component } 4 \\
\text { Institutional } \\
\text { Ownership }\end{array}$ & $\begin{array}{l}\text { Component } \\
\text { Total }\end{array}$ \\
\hline \multirow[t]{2}{*}{ Intercept (b1) } & $0.866^{* * *}$ & $1.080^{* * *}$ & $0.454^{* *}$ & $0.662^{* * *}$ & $1.046^{* * *}$ \\
\hline & $(3.45)$ & $(6.45)$ & $(2.28)$ & $(5.65)$ & $(3.23)$ \\
\hline \multirow[t]{2}{*}{$R t n_{t}(b 2)$} & 0.227 & -0.349 & -0.587 & 0.122 & -0.608 \\
\hline & $(0.41)$ & $(-1.34)$ & $(-1.57)$ & $(0.59)$ & $(-1.88)$ \\
\hline \multirow[t]{2}{*}{$\operatorname{Rtn}_{t-1}(b 3)$} & 0.318 & -0.075 & 0.398 & $0.305^{* *}$ & -0.086 \\
\hline & $(0.57)$ & $(-0.32)$ & $(1.24)$ & $(2.01)$ & $(-0.22)$ \\
\hline \multirow[t]{2}{*}{$\triangle R C G(b 4)$} & -0.002 & $-0.006^{* * *}$ & 0.003 & -0.002 & -0.001 \\
\hline & $(-1.08)$ & $(-2.57)$ & $(1.35)$ & $(-0.55)$ & $(-1.12)$ \\
\hline \multirow[t]{2}{*}{$R t n_{t} \times \triangle R C G(b 5)$} & 0.000 & $0.007^{*}$ & $0.008^{*}$ & 0.002 & $0.002^{* *}$ \\
\hline & $(-0.09)$ & (1.88) & $(1.85)$ & $(0.46)$ & $(2.34)$ \\
\hline \multirow[t]{2}{*}{$R t n_{t-1} \times \Delta R C G(b 6)$} & 0.002 & 0.006 & -0.002 & 0.001 & 0.001 \\
\hline & $(0.31)$ & $(1.63)$ & $(-0.44)$ & $(0.25)$ & $(0.93)$ \\
\hline$N$ & 178 & 169 & 162 & 196 & 151 \\
\hline$R^{2}$ & 0.102 & 0.089 & 0.089 & 0.041 & 0.052 \\
\hline
\end{tabular}

Table 6 Change in governance \& post spinoff pay-performance elasticity regressions

This table reports the coefficients on the post-spinoff pay-performance elasticity regression interacted with the change in composite corporate governance score, $\triangle R C G$, for the post-spinoff parent firms from Year +1 to Year +3 . The dependent variable for all regressions is the first difference in the log of total CEO compensation. Shareholder wealth is measured by stock return. $\triangle R C G$ is a score based on the rank of change in the average corporate governance variables of parent firms for two years before spinoff and three years after spinoff in the 4 corporate governance components as previously defined in Table 5. Component Total is a composite score which denotes the sum of all $\triangle R C G$ scores for the 4 corporate governance components. A higher value $\triangle R C G$ denotes stronger governance improvement. Other variables are previously defined. The $t$-statistics, which are based on White standard errors robust to within firms' cluster correlation, are reported in parenthesis. ${ }^{* *},{ }^{* *}$ and ${ }^{*}$ denote significance at the $1 \%, 5 \%$, and $10 \%$ level respectively. Variation in sample size is due to data availability 
from prior studies that committee independence improves firms' governance (Klein 2002; Anderson et al. 2004; and Vafeas 2003; etc.).

For the overall change in the governance score, Component Total, the coefficients for both interaction terms are positive, with the contemporaneous interaction term being significant at the $5 \%$ level. Thus, the improvements in the overall governance mechanisms have a positive influence on pay-performance sensitivity. Therefore, the evidence lends support to hypothesis H4, which is consistent with the argument from Seward and Walsh (1996) that spinoff facilitates efficient governance and control practices. Taken together, the results support our hypothesis that improvement in corporate governance mechanisms enhances CEO pay-performance sensitivity after spinoffs.

\section{Additional tests}

Given that spinoff is an outcome of a firm's choice, the spinoff sample may not represent a random one. As a result, it is possible that underlying factors that motivate firms to spin off entities can also be correlated with the improvement in pay-performance elasticity, similar to an omitted variable problem.

To address the selection bias issue, we follow Heckman's two stage regression procedure (Heckman 1979). In essence, the first stage employs the Probit model to estimate the probability that a firm undertakes a spinoff based on their underlying characteristics. The Inverse Mills ratio of the Probit regression, representing the likelihood of the spinoff decision, is obtained and entered into the second stage regression as an explanatory variable to re-estimate the pay-performance elasticity (i.e., Model 2).

For the first stage of the Heckman procedure, we obtain the matched firms by selecting one firm which has the same 4-digit SIC code, closest in size (proxied by Total Assets) as the sample firms, and in the same year and month of the spinoff distribution. The sample firms are combined with the matched firms to yield a pooled sample of 118 firms. The explanatory variables for the first stage regression include ROA (defined as operating income before extraordinary items divided by total assets), standard deviation of the past 3 years of ROAs, leverage (calculated by total debt divided by total assets), size (proxy by total assets), investment level (calculated by dividing capital expenditures by total sales), Tobin's Q (defined as the market value of total assets divided by the book value of total assets, where the market value is computed by book value of total assets plus market value of common equity minus book value of common equity and deferred taxes), the number of business segments, and the standard deviation of monthly returns. All variables for the first-stage regression are measured at Year -1 in order to represent the parent firms' characteristics immediately before the spinoff decision. The results of the first stage regression are reported in Panel A of Table 7. The results in this panel suggest that firms with poor prior performance and greater structural complexity are more likely to spin off. The inverse Mill's ratio obtained from this regression is then included as an explanatory variable to re-estimate Model (2) in the second stage.

The results of the second stage regressions are displayed in Panel B of Table 7. The estimated coefficient for the Inverse Mills ratio (Lambda) exhibits positive signs for both specifications. Yet, none of them are significant at conventional levels. Moreover, the signs of all the interaction terms are positive. This is consistent with the findings in Table 4 . 
Table 7 Second-stage results of Heckman two-stage estimation

\begin{tabular}{llll}
\hline & Coefficient & $z$-statistic & $P>|z|$ \\
\hline Panel A - First Stage PROBIT Regression Results & & \\
Intercept & 0.246 & 0.138 & 0.710 \\
ROA & 1.912 & 0.838 & 0.360 \\
Leverage & 0.818 & 0.973 & 0.324 \\
Size & -0.089 & 1.454 & 0.228 \\
Investment Level & -0.577 & 1.716 & 0.190 \\
Tobin's Q & -0.032 & 0.205 & 0.651 \\
ROA $t-2$ & -3.863 & 2.954 & $0.086^{*}$ \\
ROA $A_{t-3}$ & 1.266 & 0.496 & 0.481 \\
Std. Dev. of ROA & 1.078 & 0.093 & 0.761 \\
Number of Segments & 0.188 & 3.627 & $0.057^{*}$ \\
Std. Dev. of Returns & 1.387 & 0.016 & 0.898 \\
$N$ & & & 118 \\
Wald Statistic & & & 10.679
\end{tabular}

Panel B - Second Stage Regression Results

Dependent Variable: The log difference in Total Compensation

\begin{tabular}{|c|c|c|}
\hline & $($ Year $-1,+1)$ & (Year- \\
\hline \multirow[t]{2}{*}{ Intercept (b1) } & 0.321 & $0.483^{* *}$ \\
\hline & $(1.10)$ & (1.99) \\
\hline \multirow[t]{2}{*}{$R t n_{t}(b 2)$} & -0.228 & -0.19 \\
\hline & $(-0.75)$ & $(-0.65)$ \\
\hline \multirow[t]{2}{*}{$R t n_{t-1}(b 3)$} & -0.152 & -0.151 \\
\hline & $(-0.46)$ & $(-0.47)$ \\
\hline \multirow[t]{2}{*}{$S p D \times R t n_{t}(b 4)$} & $0.712^{*}$ & 0.535 \\
\hline & (1.8) & $(1.58)$ \\
\hline \multirow[t]{2}{*}{$S p D \times R t n_{t-1}(b 5)$} & $0.921^{*}$ & $0.669^{*}$ \\
\hline & $(1.84)$ & $(1.75)$ \\
\hline \multirow[t]{2}{*}{$S p D(b 6)$} & -0.26 & -0.1 \\
\hline & $(-1.36)$ & $(-0.59)$ \\
\hline \multirow[t]{2}{*}{ Lambda (b7) } & 0.559 & 0.306 \\
\hline & $(1.17)$ & $(0.92)$ \\
\hline N & 114 & 226 \\
\hline$R^{2} x$ & 0.15 & 0.095 \\
\hline
\end{tabular}

This table reports results on the Heckman two-stage least square regressions. The first stage estimation employs the Probit regression by pooling the spinoff and the matched sample. An indicator variable, with 1 denotes the spinoff sample and 0 denotes the matched sample is used as the dependent variable. For independent variables, ROA is defined as income before extraordinary items available for common shareholders divided by total assets. Size is measured by total assets. Leverage is defined as total debt divided by total shareholders' equity. Investment level is computed by dividing capital expenditures by total sales. Tobin's $Q$ is defined as the market value of total assets divided by the book value of total assets, where the market value is computed by book value of total assets plus market value of common equity minus book value of common equity and deferred taxes. Standard deviation of returns is the standard deviation of one year of monthly stock returns. All variables for the first-stage regression are measured at Year -1 in order to represent the parent firm fundamentals before spinoff and the data are obtained from Compustat or the CRSP database. The second stage panel regression estimation employs the parent sample for the pre- and post-spinoff period. The dependent variable for the second stage is total CEO compensation. The lambda computed from the first stage regression is included in the second stage. Other independent variables are previously defined. $T$-statistics, which are based on White standard errors robust to within firms' cluster correlation, are reported in parenthesis. ${ }^{* * *}$, * $^{*}$ and * denote significance at the $1 \%, 5 \%$, and $10 \%$ level respectively. Variation in sample size is due to data availability 
Further, both interaction terms for the first specification are significant $(p<0.1)$ whereas the lagged interaction term for the second specification is significant $(p<0.1)$. This result is again consistent with those displayed in Table 4 despite a minor decrease in significance.

Taken together, the results from the Heckman two-stage regression methodology indicate that the incremental pay-performance elasticity results are largely unaffected even with the inclusion of a sample selection bias correction term.

To ensure our findings conform to different specifications, we have conducted a few additional tests. We repeat the same analysis using return on equity (ROE) as an accounting-based measure of shareholders' wealth and the results are broadly consistent with those reported previously. For the pay-performance elasticity analysis, we repeat the same tests by including the year, industry dummies and firm size (proxied by Total Assets). The test again yields similar results. Finally, we repeat the same tests by replacing the corporate governance components using dichotomized variables rather than ranked variables and the results are qualitatively similar.

\section{Conclusions}

This study documents evidence supporting the hypothesis that spinoff improves interest alignment. We first provide evidence that $\mathrm{CEO}$ total direct compensation (including both cash and equity-based compensation) is statistically significantly associated with changes in shareholders' wealth after spinoff, whereas this association is not significant before spinoff.

Next, we extend the analysis by examining the impact of corporate governance towards the interest alignment improvement from the spinoff transaction. Four components of corporate governance mechanisms are examined in this study: board structure, committee independence, board and committee activities, and institutional ownership. The findings generally suggest that corporate governance plays some role in improving interest alignment after spinoff. In addition, we also find some evidence that stronger improvements in corporate governance enhance CEO pay-performance sensitivity.

A potential limitation of this study is that the sample is not drawn from a more recent period. Nevertheless, the more distant sample period may provide a greater opportunity to examine governance mechanisms in the absence of the extensive governance-related regulations introduced by the Sarbanes-Oxley Act of 2002. The governance arrangements and changes in those arrangements are less likely to merely comply with mandatory government regulations in the years before 2002.

\section{Endnotes}

${ }^{1}$ Prior studies such as Hite and Owers (1983), Schipper and Smith (1983), Seward and Walsh (1996) and Daley et al. (1997) have raised similar arguments. This study provides a direct test on the interest alignment argument to complement the established literature.

${ }^{2}$ The value is measured based on the abnormal return from spinoff announcements.

${ }^{3}$ Essentially, these studies suggest that pay-performance sensitivity is negatively associated with the CEO's exposure to idiosyncratic risks. Meanwhile, the association between pay-performance sensitivity and the CEO's exposure to systematic risks depends on the presence of other external factors such as the CEO's ability to trade the market portfolio, the cost for the CEO to hedge the market portfolio, etc. On the contrary, some earlier empirical studies (e.g. Garen (1994), Yermack (1995)) also could not find a significant 
relationship between a firm's risk and pay-performance sensitivity. Cichello (2005) empirically shows that the negative association between pay-performance sensitivity and a firm's risk is diminished once controlled for firm size. A recent study from Ju and Wan (2012) suggests that pay-performance sensitivity and a firm's risk bears a non-monotonic relationship. A related study from Cao and Wang (2013) shows both theoretically and empirically that the equilibrium pay-performance sensitivity is positively associated with the firm's idiosyncratic risk, yet negatively associated with the firm's systematic risks.

${ }^{4}$ The sample commences from 1990 as CEO compensation data prior to 1990 are unavailable from Execucomp or Lexis-Nexis.

${ }^{5} \mathrm{We}$ have repeated all the tests with the inclusion of these extreme samples and the results are consistent with the ones reported here. To further ensure robustness of results, we have repeated the analysis excluding firms with annual returns higher than 3.0. Again, no significant deviation of results is observed.

${ }^{6}$ Other compensation represents compensation which cannot be classified in other categories, such as life insurance premiums, retirement payments, tax reimbursements, retirement plan contributions, etc.

${ }^{7}$ This definition is consistent with Burch and Nanda (2003) and Ahn and Denis (2004).

${ }^{8}$ We also acknowledge that a number of studies find that independent / outside directors do not enhance the firms' governance (e.g., Agrawal and Knoeber (1996), Bhagat and Black (2001) etc.). However, Duchin et al. (2010) contends that the effectiveness of the outside independent directors on the board is dependent on their ability to acquire firm-specific information. Knowing that a spinoff creates value by reducing information asymmetry (e.g., Krishnaswami and Subramaniam (1999), Huson and MacKinnon (2003)), an increase in outside independent directors after the spinoff can promote more effective governance in post-spinoff firms.

${ }^{9}$ We use the pay-performance elasticity model throughout this study to examine the notion of interest alignment. The difference between pay-performance elasticity and the pay-performance sensitivity model lies solely in the measurement of the dependent and independent variables. The pay-performance sensitivity model expresses both pay and performance in dollars whereas for pay-performance elasticity, pay is expressed and logarithms and change in shareholder wealth is expressed in returns. As compared to pay-performance sensitivity, pay-performance elasticity is relatively robust to firm size (Gibbons and Murphy 1992). The use of pay-performance elasticity in this study appropriately addresses the issue of firm-size variation in the sample, along with the firm-size variation before and after the spinoff event.

Acknowledgements

We are grateful to the participants of the Asian Finance Association conference and the Frontiers of Business Research in China annual conference for their helpful comments.

Funding

Not applicable.

Availability of data and materials

Please contact author for data requests.

Author's contributions

We declare that both authors have equal contribution in this paper. Both authors read and approved the final manuscript. 


\section{Publisher's Note}

Springer Nature remains neutral with regard to jurisdictional claims in published maps and institutional affiliations.

\section{Author details}

${ }^{1}$ School of Accounting and Finance, The Hong Kong Polytechnic University, Hung Hom, Hong Kong, China. ${ }^{2}$ College of Business, City University of Hong Kong, Kowloon Tong, Hong Kong, China.

Received: 7 March 2018 Accepted: 30 October 2018

Published online: 11 December 2018

\section{References}

Adams, R., Almeida, H., \& Ferreira, D. (2005). Powerful CEOs and their impact on corporate performance. Review of Financial Studies, 18, 1403-1432.

Adams, R. B., \& Ferreira, D. (2009). Women in the boardroom and their impact on governance and performance. Journal of Financial Economics, 94, 291-309.

Aggarwal, R., \& Samwick, A. (1999). The other side of the trade-off: The impact of risk on executive compensation. Journal of Political Economy, 107, 65-105.

Agrawal, A., \& Knoeber, C. R. (1996). Firm performance and mechanisms to control agency problems between managers and shareholders. Journal of Financial and Quantitative Analysis, 31, 377-397.

Ahn, S., \& Denis, D. J. (2004). Internal capital markets and investment policy: Evidence from corporate spinoffs. Journal of Financial Economics, 71, 489-516.

Ahn, S., \& Walker, M. D. (2007). Corporate governance and the spinoff decision. Journal of Corporate Finance, 13, 76-93.

Anderson, R. C., Mansi, S. A., \& Reeb, D. M. (2004). Board characteristics, accounting report integrity and the cost of debt. Journal of Accounting and Economics, 37, 315-342

Andres, P., \& Vallelado, E. (2008). Corporate governance in banking: The role of the board of directors. Journal of Banking and Finance, 32, 2570-2580.

Armstrong, C. S., Core, J. E., \& Guay, W. R. (2014). Do independent directors cause improvements in firm transparency? Journal of Financial Economics, 113(3), 383-403.

Aron, D. J. (1991). Using the capital market as a monitor: Corporate spinoffs in an agency framework. The Rand Journal of Economics, 22, 505-518.

Beasley, M. S., Carcello, J. V., Hermanson, D. R., \& Lapides, P. D. (2000). Fraudulent financial reporting: Consideration of industry traits and corporate governance mechanisms. Accounting Horizons, 14, 441-454.

Bebchuk, L. A., Cremers, K. J. M., \& Peyer, U. C. (2011). The CEO pay slice. Journal of Financial Economics, 102, $199-221$.

Bena, J., Ferreira, M. A., Matos, P., \& Pires, P. (2017). Are foreign investors locusts? The long-term effects of foreign institutional ownership. Journal of Financial Economics, 126(1), 122-146.

Bhagat, S., \& Black, B. (2001). The non-correlation between board independence and long-term firm performance. Journal of Corporation Law, 27, 231-274.

Bizjak, J., Lemmon, M., \& Whitby, R. (2009). Option backdating and board interlocks. The Review of Financial Studies, 22, 4821-4847.

Boone, A. L., \& White, J. T. (2015). The effect of institutional ownership on firm transparency and information production. Journal of Financial Economics, 117(3), 508-533.

Burch, T. R., \& Nanda, V. (2003). Divisional diversity and the conglomerate discount: Evidence from spinoffs. Journal of Financial Economics, 70, 69-98.

Cao, M., \& Wang, R. (2013). Optimal CEO compensation with search: Theory and empirical evidence. The Journal of Finance, 68(5), 2001-2058

Carter, D., Simkins, B., \& Simpson, W. (2003). Corporate governance, board diversity, and firm value. Financial Review, $38,33-53$.

Chemmanur, T. J., Jordan, B. D., Liu, M. H., \& Wu, Q. (2010). Antitakover provisions in corporate spin-offs. Journal of Banking and Finance, 34, 813-824.

Chemmanur, T. J., Krishnan, K., \& Nandy, D. K. (2014). The effects of corporate spin-offs on productivity. Journal of Corporate Finance, 27, 72-98.

Chemmanur, T. J., \& Yan, A. (2004). A theory of corporate spin-offs. Journal of Financial Economics, 72(2), 259-290.

Cheng, S. (2008). Board size and the variability of corporate performance. Journal of Financial Economics, 87, $157-176$.

Chhaochharia, V., \& Grinstein, Y. (2009). CEO compensation and board structure. Journal of Finance, 64, 231-261.

Chou, H. I., Chung, H., \& Yin, X. (2013). Attendance of board meetings and company performance: Evidence from Taiwan. Journal of Banking \& Finance, 37(11), 4157-4171.

Cichello, M. S. (2005). The impact of firm size on pay-performance sensitivities. Journal of Corporate Finance, 11, 609-627.

Conger, J., Finegold, D., \& Lawler III, E. (1998). Appraising boardroom performance. Harvard Business Review, 76, 136-148.

Conyon, M. J., \& Murphy, K. J. (2000). The prince and the pauper? CEO pay in the United States and United Kingdom. The Economic Journal, 110, F640-F671.

Core, J. E., Holthausen, R. W., \& Larcker, D. F. (1999). Corporate governance, chief executive officer compensation, and firm performance. Journal of Financial Economics, 51, 371-406.

Cornett, M. M., Marcus, A. J., \& Tehranian, H. (2008). Corporate governance and pay-for-performance: The impact of earnings management. Journal of Financial Economics, 87, 357-373.

Crane, A. D., Michenaud, S., \& Weston, J. P. (2016). The effect of institutional ownership on payout policy: Evidence from index thresholds. The Review of Financial Studies, 29(6), 1377-1408.

Cusatis, P., Miles, J., \& Woolridge, J. (1993). Restructuring through spin-offs: The stock market evidence. Journal of Financial Economics, 33, 293-311.

Dah, M. A., \& Frye, M. B. (2017). Is board compensation excessive? Journal of Corporate Finance, 45, 566-585.

Daley, L., Mehrotra, V., \& Sivakumar, R. (1997). Corporate focus and value creation: Evidence from spinoffs. Journal of Financial Economics, 45, 257-281. 
Duchin, R., Matsusaka, J. G., \& Ozbas, O. (2010). When are outside directors effective? Journal of Financial Economics, 96, 195-214.

Fama, E., \& Jensen, M. (1983). Separation of ownership and control. Journal of Law and Economics, 26, 301-325.

Feng, Y., Nandy, D. K., \& Tian, Y. S. (2015). Executive compensation and the corporate spin-off decision. Journal of Economics and Business, 77, 94-117.

García-Meca, E., Garcia-Sanchez, I. M., \& Martínez-Ferrero, J. (2015). Board diversity and its effects on bank performance: An international analysis. Journal of Banking \& Finance, 53, 202-214.

Garen, J. E. (1994). Executive compensation and principal-agent theory. Journal of Political Economy, 102, 1175-1199.

Garvey, G., \& Milbourn, T. (2003). Incentive compensation when executives can hedge the market: Evidence of relative performance evaluation in the cross section. Journal of Finance, 58, 1557-1581.

Gertner, R., Powers, E., \& Scharfstein, D. (2002). Learning about internal capital markets from corporate spinoffs. Journal of Finance, 57, 2479-2506.

Gibbons, R., \& Murphy, K. J. (1992). Optimal incentive contracts in the presence of career concerns: Theory and evidence. Journal of Political Economy, 100, 468-505.

Green, C. P., \& Homroy, S. (2018). Female directors, board committees and firm performance. European Economic Review, 102, 19-38.

Guo, L., \& Masulis, R. W. (2015). Board structure and monitoring: New evidence from CEO turnovers. The Review of Financial Studies, 28(10), 2770-2811.

Hall, B. J., \& Liebman, J. B. (1998). Are CEOs really paid like bureaucrats? Quarterly Journal of Economics, 113, 653-691.

Hallock, K. (1997). Reciprocally interlocking boards of directors and executive compensation. Journal of Financial and Quantitative Analysis, 32, 331-344.

Hartzell, J. C., \& Starks, L. T. (2003). Institutional investors and executive compensation. Journal of Finance, 58, 2351-2374.

Heckman, J. J. (1979). Sample selection bias as a specification error. Econometrica, 47, 153-161.

Hite, G., \& Owers, J. (1983). Security price reactions around corporate spin-off announcements. Journal of Financial Economics, $12,409-435$.

Holmstrom, B. (1979). Moral hazard and observability. The Bell Journal of Economics, 10, 74-91.

Huson, M. R., \& MacKinnon, G. (2003). Corporate spinoffs and information asymmetry between investors. Journal of Corporate Finance, 9, 481-503.

Jensen, M. (1993). The modern industrial revolution, exit, and the failure of internal control systems. Journal of Finance, 48 $831-880$.

Jensen, M., \& Meckling, W. (1976). Theory of the firm: Managerial behavior, agency costs, and ownership structure. Journal of Financial Economics, 3, 305-360.

Jensen, M., Murphy, K. and Wruck, E., 2004. Remuneration: Where we've been, how we got to here, what are the problems, and how to fix them. Harvard NOM Working Paper.

Jensen, M. C., \& Murphy, K. J. (1990). Performance pay and top-management incentives. Journal of Political Economy, 98, 225-264

Jin, L. (2002). CEO compensation, diversification, and incentives. Journal of Financial Economics, 66, 29-63.

Ju, N., \& Wan, X. (2012). Optimal compensation and pay-performance sensitivity in a continuous-time principal-agent model. Management Science, 58, 641-657.

Karamanou, I., \& Vafeas, N. (2005). The association between corporate boards, audit committees, and management earnings forecasts: An empirical analysis. Journal of Accounting Research, 43, 453-486.

Klein, A. (1998). Firm performance and board committee structure. Journal of Law and Economics, 41, 275-299.

Klein, A. (2002). Audit committee, board of director characteristics, and earnings management. Journal of Accounting and Economics, 33, 375-400.

Korkeamäki, T., Liljeblom, E., \& Pasternack, D. (2017). CEO power and matching leverage preferences. Journal of Corporate Finance, 45, 19-30.

Krishnaswami, S., \& Subramaniam, V. (1999). Information asymmetry, valuation and the corporate spin-off decision. Journal of Financial Economics, 53, 73-112.

Larcker, D., Richardson, S., Seary, A., and Tuna, I., 2005. Back door links between directors and executive compensation. Working Paper, Stanford University.

Lavy, V., \& Schlosser, A. (2011). Mechanisms and impacts of gender peer effects at school. American Economic Journal: Applied Economics, 3(2), 1-33.

Lilienfeld-Toal, U. V., \& Ruenzi, S. (2014). CEO ownership, stock market performance, and managerial discretion. The Journal of Finance, 69(3), 1013-1050.

Liu, Y., \& Jiraporn, P. (2010). The effect of CEO power on bond ratings and yields. Journal of Empirical Finance, 17, 744-762.

Miles, J. A., \& Rosenfeld, J. D. (1983). The effects of voluntary spinoff announcements on shareholder wealth. Journal of Finance, 38, 1597-1606.

Morck, R. (2008). Behavioral finance in corporate governance: Economics and ethics of the devil's advocate. Journal of Management and Governance, 12, 179-200.

Morck, R., Shleifer, A., \& Vishny, R. W. (1989). Alternative mechanism for corporate control. American Economic Review, 79, 842-852.

Morse, A., Nanda, V., \& Seru, A. (2011). Are incentive contracts rigged by powerful CEOs? Journal of Finance, 66, 1779-1821.

Murphy, K. J. (1999). Executive compensation. In O. Ashenfelter \& D. Card (Eds.), Handbook of Labor Economics, vol. 3. Amsterdam: North-Holland.

Nguyen, B. D., \& Nielsen, K. M. (2010). The value of independent directors: Evidence from sudden deaths. Journal of Financial Economics, 98, 550-567.

Patro, S. (2008). The evolution of ownership structure of corporate spin-offs. Journal of Corporate Finance, 14, 596-613.

Rajan, R., Servaes, H., \& Zingales, L. (2000). The cost of diversity: The diversification discount and inefficient investment. Journal of Finance, 55, 35-80.

Rosenstein, S., \& Wyatt, J. G. (1990). Outside directors, board independence, and shareholder wealth. Journal of Financial Economics, 26, 175-191.

Scharfstein, D.S., 1998. The dark side of internal capital markets II: evidence from diversified conglomerates. Working paper, NBER. 
Scharfstein, D. S., \& Stein, J. C. (2000). The dark side of internal capital markets: divisional rent-seeking and inefficient investment. Journal of Finance, 55, 2537-2564.

Schipper, K., \& Smith, A. (1983). Effects of re-contracting on shareholder wealth: The case of voluntary spinoffs. Journal of Financial Economics, 12, 437-467.

Schwartz-Ziv, M. (2017). Gender and board activeness: The role of a critical mass. Journal of Financial and Quantitative Analysis, 52(2), 751-780

Seward, J. K., \& Walsh, J. P. (1996). The governance and control of voluntary corporate spin-offs. Strategic Management Journal, 17, 25-39.

Shin, H., \& Stulz, R. M. (1998). Are internal capital markets efficient? Quarterly Journal of Economics, 113, 531-552.

Uzun, H., Szewczyk, S. H., \& Varma, R. (2004). Board composition and corporate fraud. Financial Analyst Journal, 60, $33-43$.

Vafeas, N. (1999). Board meeting frequency and firm performance. Journal of Financial Economics, 53, 113-142.

Vafeas, N. (2003). Further evidence on compensation committee compensation as a determinant of CEO compensation. Financial Management, 32, 53-70.

Yermack, D. (1995). Do corporations award CEO stock options effectively? Journal of Financial Economics, 39, 237-269.

Yun, H. (2009). The choice of corporate liquidity and corporate governance. The Review of Financial Studies, 22, 1447-1475.

Submit your manuscript to a SpringerOpen ${ }^{0}$ journal and benefit from:

- Convenient online submission

- Rigorous peer review

- Open access: articles freely available online

High visibility within the field

- Retaining the copyright to your article

Submit your next manuscript at $>$ springeropen.com 